\title{
Socioeconomic and demographic characteristics as sources of social capital: A study of Indonesia
}

\author{
Choirul Okviyanto ${ }^{1 *}$ and Wildan Syafitri ${ }^{2}$ \\ ${ }^{1}$ Faculty of Economics and Business, Brawijaya University, and Statistics Indonesia, Indonesia \\ ${ }^{2}$ Faculty of Economics and Business, Brawijaya University, Indonesia \\ *Correspondence email: choirul.ok@gmail.com
}

\section{ARTICLE INFO}

- Research Article

Article History

Received 7 July 2021

Accepted 25 August 2021

Published 2 October 2021

\section{Keywords}

collective action; network; SPTK; tolerance; trust

JEL Classification B55; I25; 010

\begin{abstract}
Over a decade, the development in Indonesia has achieved a good performance in macroeconomic indicators: stability in the economic growth and declining trend of poverty rate; however, this development tends to ignore the social phenomena in terms of social capital, in which the social capital index decreases dramatically during the past ten years. This paper aims to examine the sources of social capital in Indonesia. Consequently, the policymakers obtain some information to improve the social capital index in Indonesia. The present study utilized the Indonesian Happiness Measurement Study (SPTK) 2017 covering 72,317 households around Indonesia and involves trust and tolerance, collective action, and group and network dimensions as a proxy of social capital. This study employed Ordinary Least Squares (OLS) analysis and found that education is essential in predicting social capital. Besides, this study confirmed that gender and location significantly affect social capital, where males and rural residents are likely to have higher social capital than females and urban residents in Indonesia. Eventually, based on research findings, this study offers some policy implementation for enhancing the social capital index in Indonesia: expanding the free educational program, encouraging women's participation in the community, and continue the village funds program.
\end{abstract}

To cite this article: Okviyanto, C. \& Syafitri, W. (2021). Socioeconomic and demographic characteristics as sources of social capital: A study of Indonesia. Journal of Socioeconomics and Development, 4(2), 212-223. https://doi.org/10.31328/jsed.v4i2.2570

\section{INTRODUCTION}

Todaro and Smith (2014) said that in addition to pursuing accelerated economic growth, poverty alleviation, and overcoming income inequality, development goals should also cover various fundamental changes to social structures, public attitudes, and national institutions. In other words, development should not only focus on achieving economic indicators but also must perceive changes in social aspects such as trust, tolerance, attitude, discipline, and collective action. However, development in Indonesia during this decade does not seem to have provided a better social change and is still too focused on economic indicator targets. Indonesia's BPS (2021) data reveals that the country has experienced an excellent economic performance in which the growth is relatively stable at around 5\% from 2009 to 2017. Besides, the development carried out by the government, successfully reducing the number of people living under the poverty line, where the poverty rate decreases gradually from $14.15 \%$ in 2009 to $10.64 \%$ in 2017 (BPS, 2020b). On the other 
hand, the social capital which encompasses trust and tolerance, collective action, and group and network, drop dramatically nearly 10 points from 57.67 in 2009 to 47.86 in 2017 (BPS, 2017b). Therefore, this paper aims to examine what determinants of social capital in Indonesia for the policymakers to obtain some information and suggestions in enhancing social capital in Indonesia.

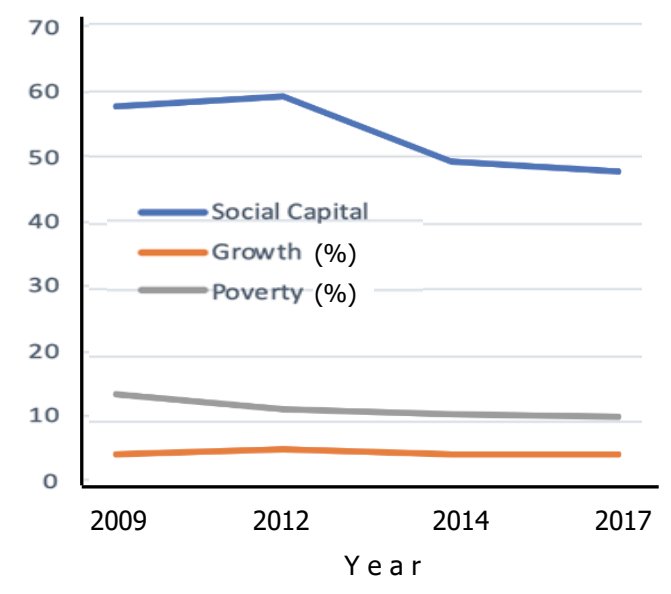

Figure 1. Social capital index, GDP growth, and poverty rate in Indonesia, 2009-2017

Several experts have carried out some studies related to the sources of social capital in various countries. For example, Hauberer (2010) conducted a study related to access to social capital in the Czech Republic. He found that social capital is formed because of socio-cultural aspects such as norms of reciprocity and trust, and ownership of collective assets such as economic, technological, and historical background, as well as individual characteristics such as gender, age, education, and ethnicity. Christoforou (2011) examined the determinants of social capital in European countries and discovered that both individual characteristics: income, education, gender, age, marital status, and employment, and macro-level factors: GDP per capita, income inequality, corruption, and unemployment, proven effect social capital in European countries. Moreover, Parts (2013) uncovered that age, income, having children associates positively with social capital, with education and democracy satisfaction as the most influential factors of social capital, while town size and individualism have a negative relationship on social capital in Europe. In Indonesia, Muzayanah, Nazara, Mahi, and Hartono (2020) investigated social capital in some cities in Indonesia and found that education, age, marital status, and gender are essential factors in perceiving most social capital dimensions Indonesia's urban areas. To conclude, those previous research revealed that individual characteristics (age, gender, marital status, education, income, number of children, employment, and residence) and aggregate factors (GDP per capita, income inequality, corruption, unemployment rate, politics, democracy, and historical background) are two major factors determining social capital. This study only focuses on examining individual characteristics as sources of social capital in Indonesia because it is crucial in perceiving the degree of social capital (Glaeser, Laibson, \& Sacerdote, 2002; Muzayanah et al., 2020; Parts, 2013; Rupasingha, Goetz, \& Freshwater, 2006).

The novelty of the current paper lies mainly in the following aspects. First, this study employs different dimensions of social capital: trust and tolerance, collective action, and group and network, which cover 24 indicators. Secondly, while some previous studies, particularly in Indonesia, utilized the data from the multipurpose surveys such as The National Socioeconomic Survey (Susenas) or The Indonesia Family Life Survey (IFLS) to measure social capital, the current study uses The Happiness Measurement Study (SPTK). SPTK is the only study that focuses on measuring happiness and social capital in Indonesia. Besides, this article involves more potential sources of social capital than previous studies in Indonesia: age, gender, married, education, location, income, employment, and leisure time. Eventually, this research may offer some recommendations and suggestions for policymakers regarding improving Indonesia's level of social capital based on the results.

\section{RESEARCH METHOD}

This study utilized secondary data of SPTK, a unique study to measure happiness index and social capital index in Indonesia, conducted by BPS on 5-30 April 2017. SPTK uses a two-stage one-phase sampling method (BPS, 2017b, 2017a), with 72,317 households a total samples from all provinces (34 provinces) and districts/cities (487 districts/cities) in the rest of Indonesia. In the survey, not all household members could be selected as respondents because several questions, such as work, household income, and family harmony, could only be answered accurately by the head of the household or his partner. 
Therefore, the head of the household or spouse was chosen as the respondent to represent the household. Hence, individuals in this paper are heads of households or their partners.

Before examining the data to obtain determinants of social capital, the present study needed to calculate the social capital dimension index first, adopting the method by BPS (2009) as follows. The first step was factor identification by Principle Component Analysis (PCA). As mentioned before, the social capital in SPTK covers three dimensions, seven sub-dimensions, and 24 indicators. Each indicator has a particular contribution to social capital in which the contribution is not determined by the same value or based on subjective assessments. However, it was calculated based on data distribution using statistical methods, namely PCA as a factor extraction method. The criteria considered for assessing whether the resulting factor arrangement at a particular calculation stage is the most optimal were as follows: score of eigen values was more than one, percentage of variances was at least 60 percent, and the score of loading factors for each variable was greater than 0.4 . Variables that did not meet these criteria were excluded from the dataset and followed by iterative program execution of the dataset's remaining variables. The composition of factors resulting from the PCA process produced eight factors, including 23 variables, and explained the diversity of data by 69.34 percent.

The second step was measuring the weight of each variable. Each variable's weight was calculated based on the loading factor's value on the variable in question and the rotation sums of squared loading (\% of variance) on the formed factors. The weight measurement for each variable was carried out in 2 (two) stages: determining the weight of each variable in factors with the formula:

$$
W=\frac{L F}{T L F} \times R S S L
$$

where $W$ is weight; $L F$ is loading factor; $T L F$ is total loading factor in one factor; RSSL is rotation sums of squared loading (\% of variance). After that, the normalized weight of each variable in the dimension was determined with a formula:

$$
w=\frac{w}{R S S L D}
$$

where $w$ is the normalized weight; $W$ is weight; $R S S L D$ is rotation sums of squared loading (\% of variance) in one dimension. The results of data processing with factor analysis and the weight of each variable are presented in appendix 1.

The last step was measuring the score of social capital dimensions. Each individual's social capital dimension index was calculated by multiplying each variable's normalized weight by the score of each variable obtained by the individual.

$$
d_{i}=\sum_{j} w_{i j} x_{j}
$$

Where, $d_{i}$ for the $i$-th score of social capital dimension; $\mathrm{w}_{\mathrm{ij}}$ for the $j$-th normalized weight of variables and $i$ th dimension; $x_{j}$ for the $j$-th score of variables.

Since the social capital scores ranged from 1 to 4 , it needed to be transformed into an index value ranging from 0 to 100 . This index is known as the Social Capital Dimension Index, and the current research employs this index as an approach of social capital aspects. The social capital dimension index formula is as follows:

$$
D_{i}=d_{i} \times 25
$$

Where $D_{i}$ for the $i$-th of social capital dimension index owned by each respondent on a scale of 0-100; while $d_{i}$ for the $i$-th score of the social capital dimension for each respondent, which is still on a scale of 1-4.

After calculating the social capital dimension index, the current paper adopts Muzayanah et al. (2020) formula at the individual level by involving some modifications to examine sources of social capital in Indonesia. If it used Logistic Regression Model (Logit), this research engages Ordinary Least Square (OLS) with the numerical dependent variable and adds broader potential determinants of social capital. The analysis model in this study is as follows:

$$
\begin{aligned}
S C_{i}= & \beta_{0}+\beta_{1} \text { Age }_{i}+\beta_{2} \text { Age }_{i}^{2}+\beta_{3} \text { Gender }_{i}+ \\
& \beta_{4} \text { Marital }_{i}+\beta_{5} \text { Edu }_{i}+\beta_{6} \text { Inc }_{i}+\beta_{7} \text { Emp }_{i}+ \\
& \beta_{8} \text { Loc }_{i}+\beta_{9} \text { Leisure }_{i}+\varepsilon_{i}
\end{aligned}
$$

where, $S C_{i}$ for the degree of social capital index (trust and tolerance, collective action, and group and network); Age for age of respondent; Gender for gender of respondent; Marital means marital status (single, married, widow/divorce); Edu for attainment education level (no education, primary, secondary, and tertiary); Inc for income level (<Rp. 1,000,000, Rp. $1,000,001-1,500,000$, Rp. $1,500,001-2,500,000$, Rp. 2,500,001-4,000,000, >Rp. 4,000,000); Emp for employment status; Loc for living location (urban and rural); Leisure for leisure time. 


\section{RESULT AND DISCUSSION}

\section{Social Capital in Indonesia}

According to BPS (2017b), Indonesia has experienced a downward trend of the social capital index in nearly a decade. In 2009, social capital in Indonesia reached the point of 57.67, and it increased slightly to 59.34 in 2012. After that, Indonesia's social capital dropped dramatically, almost 10 points, to 49.45 in 2014. In the last measurement of social capital by BPS in 2017, it was only 47.86 . Regarding the comparison of social capital among provinces in Indonesia, the highest three of social capital index were D.I Yogyakarta (55.14), Central Java (54.77), and North Sulawesi (53.25). At the same time, Riau (38.71), East Kalimantan (41.33), and DKI Jakarta (41.66) were provinces with the bottom three of social capital index in 2017.

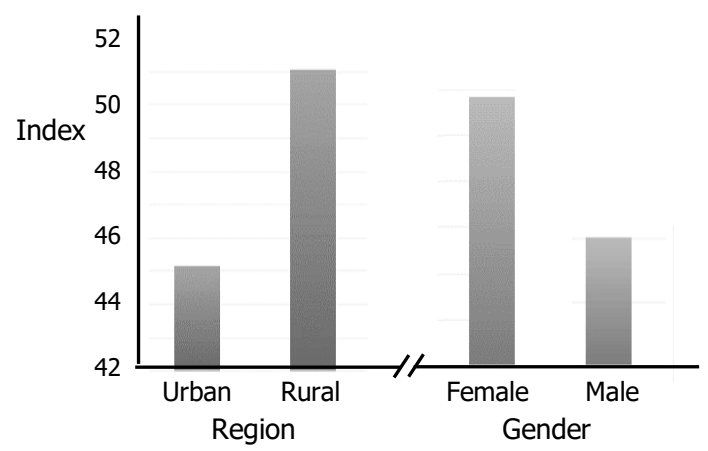

Figure 2. Social capital index by region and gender in Indonesia, 2017

In term of region classification, Indonesians who live in rural areas tended to have social capital index higher (51.05) than people who live in urban areas (45.16). The difference between urban and rural areas can also be found in the difference in dimensional indices. The most striking difference is primarily in collective action and reciprocity dimensions, with the rural index of 57.49 while the urban one is 49.61 . This difference shows that rural residents tend to carry out collective action and act reciprocally compared to urban residents in Indonesia. Additionally, males had social capital index better than females in Indonesia, 49.86 and 46.00 respectively. If viewed based on the social capital index per dimension, some differences tend to be large, especially in the social capital index of group and network dimensions, where the dimension index for males was 38.46 while females only 32.77 .

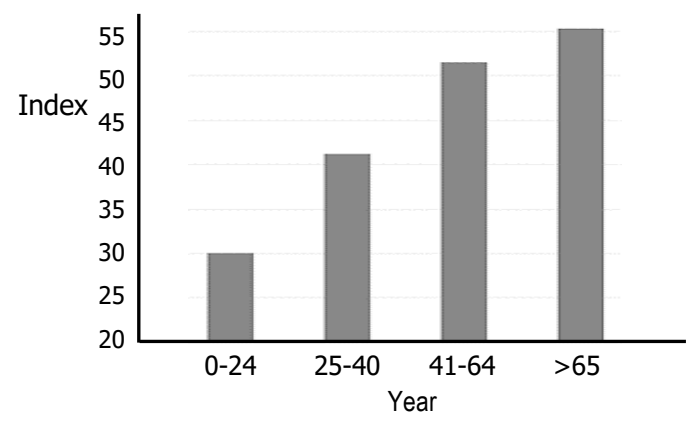

Figure 3. Social Capital Index by Age Group in Indonesia, 2017

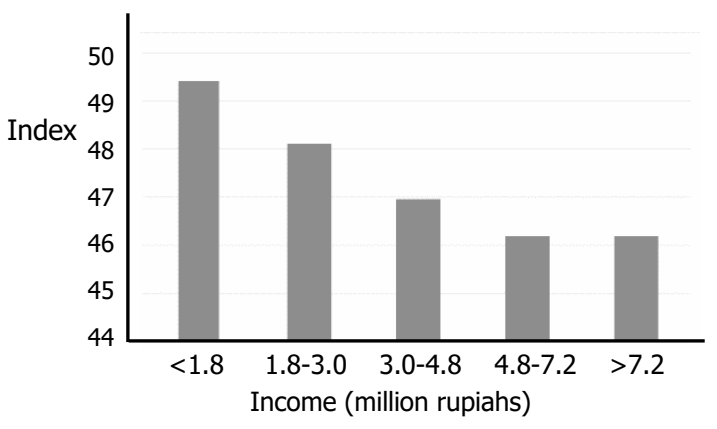

Figure 4. Social capital index by household's income group per month in Indonesia, 2017

Furthermore, BPS (2017b) records that the unmarried population had the lowest social capital index (35.32), lower than the married population (47.76). Meanwhile, the widowed had the highest social capital index (52.08) compared to the unmarried, married, and divorced (48.13) in Indonesia in 2017. Judging from the dimensions that make up the social capital index, the three dimensions show that a person with widowed status has a larger dimension index compared to other statuses, which was 60.89 for the dimensions of trust and tolerance, 56.98 for the dimensions of collective action and reciprocity, and 52.08 for the dimensions of groups and networks. Besides, Figure 4 shows that in Indonesia, people in the older age group have a greater social capital index. The population aged 24 years and under had the lowest social capital index, 30.01 . Whereas the population aged $25-40$ years had an index of 41.18, the 41-64 year age group had a social capital index of 51.55, and the population aged 65 years and over was 55.34. Therefore, it can be 
concluded that the value of the social capital index increases as a person age, or the social capital index is directly proportional to age.

Following the demographic characteristics, Figure 5 reveals that economic characteristics in terms of income differences also yield various social capital indexes in Indonesia. In 2017, people who earned more than IDR 7,200,000 had the smallest social capital index compared to other income groups, 46.19. The opposite happens to residents with an income of IDR $1,800,000$ and below, who had the largest social capital index, 49.39. Likewise, each larger income group has a smaller social capital index when compared to the smaller income group. Based on its dimensional index, the lower-income group has a higher dimension index for either group and network dimension indexes, collective action and reciprocity dimension indexes, or trust and tolerance dimension indexes. In addition, when viewed based on the subdimensional index, a striking difference is found in the trusting attitude sub-dimension index. For households with an income of more than Rp. 7,200,000, the trust attitude dimension index was 56.72 and continued to increase until it reached 66.49 in the group of households with an income of less than Rp. 1,800,000. This data illustrates that the lower the household income is, the higher is the tendency to trust.

\section{Sources of Social Capital}

This section explains whether independent variables: age, gender, marital status, education, income, employment, location, and leisure time influence dependent variables (trust and tolerance, collective action, and group and network) in Indonesia by examining the sign, level, and statistical significance of the coefficient on variables on regression outputs. Besides, this section tries to explore more why the statistical results happened by comparing to previous findings and current phenomena, particularly in Indonesia. Eventually, at the end of the section, the study provides some recommendations and suggestions for policymakers on improving Indonesia's level of social capital based on research findings.

Table 1 reveals that age is an important variable to predict social capital in Indonesia. It has a strong relationship on all social capital dimensions at a $1 \%$ confidence interval level. Even though the sign shows that the effect of age on social capital is mix in which age positively impacts trust and tolerance, and

collective action, but has a negative impact on group and network. In addition, age square has a significant negative effect on all social capital dimensions at a $1 \%$ significance level. It implies that age has an inverted U-shape relationship with social capital. Regarding gender and marital status, males significantly had higher social capital dimension index levels than females at a $1 \%$ level of significance. At the same time, singles tend to have a higher level of trust and tolerance compared to the married and divorced/widowed. Yet, singles are likely to have less collective action and group and network index than married and divorced/widowed at $1 \%$ level of the confidence interval. Table 1 also informs that education level has a strong and significant effect on social capital at a $1 \%$ significance level. While income seems enormously significant relationship on trust and tolerance dimension, tend to insignificant on collective action dimension, and is likely fragile on a group and network dimension. Employment status has no significance on trust and tolerance but is strongly significant on collective action and group and network. Finally, location and leisure time proven empirically having a significant effect on social capital index though have a different sign among social capital dimensions.

Table 1. Variables Estimate Affecting Social Capital

\begin{tabular}{|c|c|c|c|}
\hline $\begin{array}{l}\text { Explanatory } \\
\text { Variables }\end{array}$ & $\begin{array}{l}\text { Trust and } \\
\text { Tolerance }\end{array}$ & $\begin{array}{c}\text { Collective } \\
\text { Action }\end{array}$ & $\begin{array}{l}\text { Group and } \\
\text { Network }\end{array}$ \\
\hline Age & $0.0518 * * *$ & $0.8688^{* * *}$ & $-1.0933 * * *$ \\
\hline Age2 & $-0.0004 * * *$ & $-0.0078 * * *$ & $-0.0093 * * *$ \\
\hline Gender & $1.1193 * * *$ & $1.2213 * * *$ & $4.0955 * * *$ \\
\hline \multicolumn{4}{|l|}{ Marital Status: } \\
\hline Married & $-0.9837 * * *$ & $7.6285^{* * *}$ & 8.3394*** \\
\hline Divorced & $-0.9935 * * *$ & $4.1465^{* * *}$ & $4.3390 * *$ \\
\hline \multicolumn{4}{|l|}{ Education: } \\
\hline Primary & $0.3301 * * *$ & $2.7537 * * *$ & $4.2676 * * *$ \\
\hline Secondary & $1.4018^{* * *}$ & $3.8753 * * *$ & $8.3721 * * *$ \\
\hline Tertiary & $2.3556 * * *$ & $5.0914 * * *$ & $13.2957 * *$ \\
\hline \multicolumn{4}{|l|}{ Income (rupiahs) } \\
\hline $1.0-1.5$ & $0.3206^{* * *}$ & $0.3300 * *$ & $31^{* *}$ \\
\hline $1.5-$ & $0.8176^{* * *}$ & 0.0520 & 0.0723 \\
\hline 2.5-4.0 million & $0.4723 * * *$ & -0.2909 & $0.7569 * * *$ \\
\hline$>4.0$ million & $0.8061^{* * *}$ & -0.3573 & $-0.7729 * *$ \\
\hline Employment & 0.0892 & $2.2292 * * *$ & $3.2723 * * *$ \\
\hline Location & $-0.3405^{* * *}$ & $-3.0135 * * *$ & $-3.4729 * * *$ \\
\hline Leisure Time & $0.0091 * * *$ & $0.0060 * *$ & $-0.0189 * * *$ \\
\hline Constanta & $63.708 * * *$ & $30.535^{* * *}$ & $-3.0737 * * *$ \\
\hline Obser & 72,317 & 72,317 & 72,317 \\
\hline Prob ( & 0.000 & 0.000 & 0.000 \\
\hline R-squared & 0.0176 & 0.0949 & 0.1019 \\
\hline
\end{tabular}


Furthermore, the research finding, as in Table 1, confirms some previous social capital study results. For example, age turns out to influence essentially as determinants on social capital (Christoforou, 2005; Kaasa \& Parts, 2008; Parts, 2013) in which higher age yields bigger trust (Van Oorschot \& Finsveen, 2010) and collective action dimensions (Muzayanah et al., 2020), In contrast, older people and retirees tend to avoid participating in formal and informal networks (Kaasa \& Parts, 2008; Parts, 2013). According to Lambert et al. (2006), social capital is the result of the accumulation of a person's experience during their life which is along with increasing age. The more mature a person's age, the more awareness to interact in the social community, which improves the degree of social capital. On the other hand, diversity of cultural tradition leads to elderly and retirees have less participation in community meetings and group members among countries. It is different from developed countries where older people tend to live apart from family and nursing home, causing them to participate in a voluntary group to escape from loneliness and alienation (Veenhoven, 1989). In Indonesia, nursing homes for elders are not common, and the elders prefer to live and spent their retirement with their families so that they may not feel lonely.

Moreover, the present paper results support the prior studies conducted by Glaeser et al. (2002), Muzayanah et al. (2020), and Rupasingha et al. (2006) who discovered that the life cycle hypothesis exists in the relationship between age and social capital. This theory said that level of social capital increases and reaches the peak at productive age (18 to 40 ); after that, social capital decreases when people get older. In addition, this research confirms that the life cycle hypothesis occurs in trust and tolerance, and collective action dimensions, but it disappears in the group and network dimensions. Using Wooldridge's (2013) formula to calculate the turning point, this study found that the age to reach the maximum trust and tolerance and collective action in Indonesia is 65 and 56, respectively. At the same time, Table 1 reveals that participating in community meeting and group in Indonesia drop dramatically when the individual gets older. This finding contradicts Christoforou's (2011) study, stating that participating in group membership rises in both the younger and older groups. As mentioned in the previous paragraph, the variety of cultural traditions may lead the contradiction to occur.
With regard to gender, differences of gender still matter concerning predicting the level of social capital aspects in Indonesia. Particularly, in participating in community meetings and group membership, males involve dominantly in this aspect where the regression coefficient is highest among other aspects. In line with Mondéjar Jiménez, Mondéjar-Jiménez, MeseguerSantamaría, and Vargas Vargas' (2011) finding that gender differences are empirically proven to impress social capital components: institutional trust, social participation, and political participation in Central Europe countries. In the case of Indonesia, around $35 \%$ females at age 15 and over serve as a housekeeper in their own families: looking after the children and doing house chores (BPS, 2021b). It probably causes women to tend to have high networking inside their families (Christoforou, 2011). However, they face the barrier to join some groups outside the household, such as voluntary organizations and unions (Alawiyah \& Held, 2015), which become approaches group and network aspect in this study. Besides, arisan, one of the unique activities related to community interaction in Indonesia (Hardini \& Wasiaturrahma, 2020) which primarily involves females compared to males, has an immense contribution to enhancing the level of collective action aspects. It may yield relatively low regression coefficient differences of collective action between genders (1.2213) compared to the group and network aspects. In addition, the present study strongly supports the preceding arguments (Christoforou, 2005; Hauberer, 2010; Kaasa \& Parts, 2008) that males appear to have a higher level of the social capital index.

In term of gender, the current study discovers that married and divorced/widowed probably have higher collective action and participation in group and network than singles in Indonesia. It is possibly because for Indonesians, marriage is a sacred bond not only between 2 individuals but also two big families. BPS (2017a) added that marriage is part of human social relations in society based on various personal interests and goals and is followed by social considerations. The bonds created resulting from marriage are as strong as blood ties, thereby increasing social networks and collective activities between these individuals. Besides, the individual who has married and creates family will lead to their expenditure rise (Rustiadi \& Nasution, 2017) in terms of consumption, housing, education, and health. As a 
result, those life necessities encourage individuals to take part in the community and attract to work together with others to get some benefit for their interests (Jumirah \& Wahyuni, 2018).

The interesting finding of this paper is that education appears to play a crucial role in Indonesia's sources of social capital. The biggest score of education coefficient on all social capital components indicates that education is the essential element determining social capital in Indonesia. For instance, in the relationship between the level of education and group and network components, the individual who has tertiary education attainment probably have around 13 points of group and network index higher than people with no education. Fidrmuc and Gërxhani (2004) added that individual who has higher education or is currently studying would have the opportunity to participate in voluntary activities or organizations and have more social networks. Additionally, the statistical results exhibit that the higher level of education generates a higher degree of trust and tolerance, collective action, and group and network components, as found by earlier research (Lee, Yoo, Ha, \& Seo, 2018; Mondéjar Jiménez et al., 2011; Muzayanah et al., 2020; Parts, 2013). In Indonesia, only 9.5\% population graduated from the tertiary educational level in 2020 (BPS, 2020c), so people see those graduates as the problem solvers of various issues in the neighbourhoods and the communities. In addition, someone who has a higher level of education will enhance their chances of getting a job and a more decent position: civil servants, professional, managerial, and administrative positions. Therefore, it presents an important role and high social status for individuals in the community, neighbourhoods, and work (Budiati \& Rochmat, 2020).

In term of the role of income variable in estimating level of social capital in Indonesia, the empirical evidences show that the effect of income on social capital aspects is fragile. As mentioned, income is likely to be important for trust and tolerance aspects, is not significant to predict collective action, and destabilize relationships on group and network aspects. Uslaner (2002) remarked that higher and growing income produce optimism for individual, leading to increasing trust among each other. In parallel, Ananyev and Guriev (2019) recorded a decreasing $5 \%$ social trust in Russia caused by a declining $10 \%$ in income. They added that the risk aversion and the beliefs about the fairness of the world caused by declining income are two reasons why people lose trust to others. Hence, optimism and fair feeling produced by growing income may also create trust others among Indonesian. Moreover, the regression results indicate that for Indonesian, income is not the main consideration for helping each other and working together. For example, when a neighbour is struck by a disaster or needs help, Indonesian people will be happy to help according to their respective abilities, regardless their income. Apparently, economic factors in term of income have not been able to replace the long-established norms and beliefs for Indonesian citizens.

Another variable referring to the spectrum of individual determinants questioned in the empirical observation is employment status. The regression output indicates that the individual with a job can cooperate with others and participate more actively in group and community meeting compared to the unemployed in Indonesia. In line with the prior studies, which discovered that the people without jobs seem likely to keep away from partaking social activities for public interests (Dieckhoff \& Gash, 2015; Kunze \& Suppa, 2017). The explanation for it is that the unemployed probably spend their leisure time involved in the labor market and seeking a job so that they do not have enough time to take part in social activities. Likewise, Kunze and Suppa (2017) remarked that the jobless seem likely to be interested in being engaged in a personal relationship with those considered owning a channel to a job opportunity. Hence, they might avoid participating in a community meeting or group memberships which is judged as wasting their time without the certainty of getting a job.

Next, the current paper points out location as the individual factor that likely determines social capital in Indonesia. Once again, the results strongly prove the earlier studies that villagers likely have higher social capital than urban residents (BPS, 2017b; Muzayanah et al., 2020; Rupasingha et al., 2006). This study also claims the superiority of rural residents in Indonesia on all social capital dimensions: trust and tolerances, collective action, and group and network. Contrarily, Sørensen (2012, 2014) examined whether rural residents had better social capital than urban residents in Denmark. He concluded that social capital in rural areas is not higher than in urban areas: voluntary associational work is higher in rural areas than urban areas, while trust and association membership is 
equally high in rural and urban areas. In Indonesia, high-density, ethnic diversity, and rapid speed of activities in cities may weaken traditional ties (Wang, Xue, Liu, Chen, \& Qiu, 2018), and people tend to avoid taking part in community meetings or group memberships. In addition, gotong royong, the unique Indonesians' rural areas tradition in which people work together to overcome common problems in terms of building infrastructures and public facilities, probably causes social capital in rural areas to be better than in urban areas.

The last point worth noting from the current paper is how the leisure time variable influences social capital in Indonesia. The research finding exposes that leisure time has an inconsistent effect concerning social capital in Indonesia. On the one hand, individual with longer leisure time seems likely to enjoy more trust and tolerance, and collective action. On the other hand, longer leisure time means less participation in community meetings and group memberships. Conversely, Lindström (2011) and van Ingen and van Eijck (2009) revealed that leisure time, particularly leisure-time physical activities, positively influences social capital indicators: trust, civic engagement, and helping. A possible explanation for this is that most Indonesian people prefer to spend their leisure time taking a rest (watching tv and listening to music), having recreation with family or friends, socializing with neighbors, and doing hobbies rather than attending group or community meetings. SPTK 2017 revealed that more than $80 \%$ of respondents spend their time taking a rest and socializing with neighbors. Therefore, leisure time might improve trust and tolerance among individuals in the neighborhoods, but it diminishes community meetings and group membership involvement.

\section{Research Implication}

Based on those findings, the current study would like to offer policymakers some suggestions to enhance the social capital level, particularly in Indonesia. First and foremost, because education plays an essential role in social capital, the policymakers should consider expanding the educational program that frees up not only school fees from elementary to high schools but also free university fees for all. Recently, there were only $9.5 \%$ of people who owned university diplomas in Indonesia in 2020 (BPS, 2020c). This number may increase rapidly by low-cost education so that more people with a well-educated can give higher contribution and participation to their communities. Budiati and Rochmat (2020) added that in the context of Indonesia, social status has the critical key for social interaction in the communities; when the individual has a higher level of social strata, the more tremendous respect is given for them. They also stated that the best way to lift the social status in the communities is through a higher level of education. In other words, a higher level of education will improve the level of social capital in Indonesia.

Secondly, the policymakers should encourage women's participation in their communities by funding, coaching, and supporting small-micro enterprises involving mothers and women as employees or entrepreneurs, especially in rural areas. BPS (2020a) recorded that although gender inequality in Indonesia experiences a declining trend for nearly two decades, it is still higher than the average of the world and East Asia and Pacific countries. Moreover, gender inequality, including women's participation in parliament and labor force participation in rural areas, tends to be higher than in urban areas. The attention and full support of the government for the woman cooperative (Koperasi Wanita) will provide access for women to be more involved in collective action, network, trust, and norm (Widiyanti, Pudjihardjo, \& Saputra, 2018) without abandoning their household obligation. Hence, it might raise women's empowerment and achieve social capital equality for Indonesian.

Thirdly, the village community empowerment programs through village funds (Dana Desa) and labor-intensive programs should be continued. According to Mutolib, Nikmatullah, \& Effendi (2019), the village funds program had contributed to improving the village-owned enterprises (BUMDes), in which the village government allocated around $25 \%$ of the budget total for establishing and improving community economic business. Moreover, Welan, Kawung, and Tumangkeng (2019) remarked that community participation and village community empowerment increased because of the village funds program. In parallel, Zeho, Prabowo, Estiningtyas, Mahadiansar, and Sentanu (2020) found that accountability in managing village funds involving stakeholders' collaboration strengthens society participation in assessing program activities. Therefore, excellent and transparent village fund management should improve welfare and social 
capital in the countryside. In addition to encouraging collective action among villagers and providing employment opportunities, the program can reduce urbanization which results in high density in urban areas. For example, before the COVID-19 outbreak, there was a lot of community-based tourism programs in Indonesian's village such as Kampung Pujon Kulon in Malang and Umbul Ponggok in Klaten that provided job opportunities for youth or fresh graduates and avoided labor force mobility to the cities.

Finally, to respond to the current situation under COVID-19 outbreak, the policymakers still need to maintain social capital in communities without face-toface interaction among members by optimization the role of digital communication: television and social media. Pitas and Ehmer (2020) stated that enhancing adherence to and promoting efficacy, physical distancing, avoiding the crowd, staying at home, and other protecting actions will succeed if the communities have high social capital. Furthermore, they added that policymakers at the village and neighborhood level can utilize social media: Facebook, Twitter, Instagram, and WhatsApp groups, to spread curated, accurate information about the pandemic and actively eliminate conceivably dangerous misinformation. With excellent infodemic management, trust in the government will increase through adherence to communities on health protocols (Nugroho, 2020). As a result, people in some communities agree to do collective action to help their neighbors who are in self-quarantine due to COVID-19 infection and to prevent the virus spreading in their communities.

\section{CONCLUSION AND SUGGESTION}

BPS (2017b) stated that a community with high social capital can solve problems more efficiently because there has been good cooperation with each other. In contrast, communities with low social capital will find it more difficult to solve problems. The differences in social capital that exist usually vary between groups based on their socioeconomic and demographic characteristics. In Indonesia, people in rural areas tend to have a higher social capital index than those who live in urban areas, males have better social capital index than females in Indonesia, people in the older age group have a greater social capital index, and larger income group has a smaller social capital index when compared to the smaller income group. In general, Indonesia has experienced a declining trend of social capital over the last decades. This study is present to explore the determinants of social capital dimensions: trust and tolerance, collective action, and group and network in Indonesia. By knowing what the sources of social capital are, this paper hopes that policymakers will get some input regarding how to increase the social capital index in Indonesia. In order to obtain those objectives, the current study utilizes data of SPTK 2017 conducted by BPS and examines some individual factors that can potentially affect the social capital index in Indonesia.

According to the empirical evidence, this paper declares that education is the most important factor concerning sources of social capital in Indonesia. Education appears to have a significant and positive effect on all social capital dimensions. Besides, education has the highest coefficient among individual factors tested in the model analysis. Following education, gender is significantly proven to hold a relationship on social capital, in which males seem likely to possess a higher level of all social capital aspects than females in Indonesia. The next individual factor that significantly affects Indonesia's social capital is the location, where individuals living in rural areas tend to enjoy higher trust and tolerance, collective action, and group and network than urban residents. Regarding age, marital status, and leisure time, they have mixed associations with social capital. Although those variables significantly affect all social capital components, they likely have contradictory influence among social capital dimensions. In addition, employment status has a tendency to raise the level of collective action and group and network, but it does define the level of trust and tolerance. Eventually, this paper finds that income is the most fragile individual factor in prognosticating social capital compared to other factors in the model. It is only significant on trust and tolerance aspects, leading to irrelevant in providing collective action, and seems likely unstable to predict the level of participating in community meetings and joining groups.

The present paper suggests that policymakers can enhance the social capital in Indonesia by expanding the educational program, encouraging women's participation in their communities, continuing the village community empowerment programs, and optimizing the role of digital communication in the pandemic. 


\section{REFERENCES}

Alawiyah, T., \& Held, M. L. (2015). Social capital: promoting health and well-being among Indonesian women. Affilia - Journal of Women and Social Work, 30(3), 352-362. https://doi.org/10.1177/0886109915572842

Ananyev, M., \& Guriev, S. (2019). Effect of income on trust: Evidence from the 2009 economic crisis in Russia. Economic Journal, 129(619), 1082-1118. https://doi.org/10.1111/ecoj.12612

BPS. (2009). Statistik Modal Sosial 2009. Badan Pusat Statistik.

BPS. (2017a). Indeks kebahagiaan 2017. In A. Na'im, D. Aryanti, Karmaji, \& T. Suryaningsih (Eds.), Badan Pusat Statistik. Jakarta: BPS.

BPS. (2017b). Statistik Modal Sosial Tahun 2017. Badan Pusat Statistik.

BPS. (2020a). Kajian Perhitungan Indeks Ketimpangan Gender. Retrieved from https://www.bps.go.id/publication/download.html ?

BPS. (2020b). Percentage of Poor People by provinces, 2009-2017. June 20, 2021, Retrieved from https://www.bps.go.id/subject/12/kependudukan. html\%0Ahttps://www.bps.go.id/ indicator/11/104/2/-seri-2010-laju-pertumbuhanpdb-seri-2010.html

BPS. (2020c). Welfare Statistics 2020. Jakarta: BPSStatistik Indonesia.

BPS. (2021a). Growth Rate of GDP 2010 Version, 2020. https://doi.org/10.1055/s-2008-1040325

BPS. (2021b). Labor force situation in Indonesia: Februari 2021. Jakarta.

Budiati, S., \& Rochmat, S. (2020). The Impact of education on social stratification and social mobility in communities in Indonesia. Advances in Social Science, Education and Humanities Research, 398(ICoSSCE 2019), 75-78. https://doi.org/10.2991/assehr.k.200130.016

Christoforou, A. (2005). On the determinants of social capital in greece compared to countries of the European Union. SSRN Electronic Journal, 1-28. https://doi.org/10.2139/ssrn.726142

Christoforou, A. (2011). Social capital across european countries: Individual and aggregate determinants of group membership. American Journal of Economics and Sociology, 70(3), 699-728. https://doi.org/10.1111/j.15367150.2011.00793.x
Dieckhoff, M., \& Gash, V. (2015). Unemployed and alone? Unemployment and social participation in Europe. International Journal of Sociology and Social Policy, 35(1/2), 67-90. https://doi.org/10.1108/IJSSP-01-2014-0002

Fidrmuc, J., \& Gërxhani, K. (2004). Formation of social capital in Eastern Europe: Understanding the Gap Vis-a-Vis Developed Countries (April 2005). http://dx.doi.org/10.2139/ssrn.729324

Glaeser, E. L., Laibson, D., \& Sacerdote, B. (2002). An economic approach to social capital. Economic Journal, 112(483). https://doi.org/10.1111/14680297.00078

Hardini, M., \& Wasiaturrahma. (2020). Social capital dimensions and individual happiness in Indonesia : The micro-level study. Jurnal Ekonomi Pembangunan, 18(December), 147-162. Retrieved from https://ejournal.unsri.ac.id/ index.php/jep/article/view/12753

Hauberer, J. (2010). Social Capital Theory: Towards a Methodological Foundation. VS Verlag für Sozialwissenschaften. https://books.google.co.id/ books?id=gbeBNQEACAA J

Jumirah, J., \& Wahyuni, H. (2018). the Effect of social capital on welfare in Indonesia. Journal of Indonesian Economy and Business, 33(1), 65-76. https://doi.org/10.22146/jieb.29219

Kaasa, A., \& Parts, E. (2008). Individual-level determinants of social capital in Europe: Differences between country groups. Acta Sociologica, 51(2), 145-168. https://doi.org/10.1177/0001699308090040

Kunze, L., \& Suppa, N. (2017). Bowling alone or bowling at all? The effect of unemployment on social participation. Journal of Economic Behavior and Organization, 133, 213-235. https://doi.org/10.1016/j.jebo.2016.11.012

Lambert, T. A., Eby, L. T., Reeves, M. P., Lambert, T. A., Eby, L. T., \& Reeves, M. P. (2006). Predictors of networking job seekers. (706), 351-365. https://doi.org/10.1177/0894845305282767

Lee, S., Yoo, C., Ha, J., \& Seo, J. (2018). Are perceived neighbourhood built environments associated with social capital? Evidence from the 2012 Seoul survey in South Korea. International Journal of Urban Sciences, 22(3), 349-365. https://doi.org/10.1080/12265934.2017.1396909

Lindström, M. (2011). Social capital, desire to increase physical activity and leisure-time physical activity: A population-based study. Public Health, 125(7), 442-447. https://doi.org/10.1016/j.puhe.2011.01.015 
Mondéjar Jiménez, J., Mondéjar-Jiménez, J.-A. Meseguer-Santamaría, M.-L., \& Vargas Vargas, M. (2011). An empirical assessment of individual-level determinants of social capital in Central Europen countries. Journal for East European Management Studies, 16(3), 237-250. Retrieved from http://www.jstor.org/stable/23281689.

Mutolib, A., Nikmatullah, D., \& Effendi, I. (2019). Kontribusi dana desa dalam pembangunan badan usaha milik desa di Desa Hanura, Kabupaten Pesawaran, Provinsi Lampung. JSHP : Jurnal Sosial Humaniora Dan Pendidikan, 3(1), 10-19. https://doi.org/10.32487/jshp.v3i1.535

Muzayanah, I. F. U., Nazara, S., Mahi, B. R., \& Hartono, D. (2020). Is there social capital in cities? The association of urban form and social capital formation in the metropolitan cities of Indonesia. International Journal of Urban Sciences, 24(4), 532-556. https://doi.org/10.1080/12265934.2020.1730934

Nugroho, I. (2020). Fostering online social capital during the COVID-19 pandemic and new normal. Journal of Socioeconomics and Development, 3(2), 74. https://doi.org/10.31328/jsed.v3i2.1640

Parts, E. (2013). The dynamics and determinants of social capital in the European union and neighbouring countries: Theory and practice of economic policy in the European Union. http://dx.doi.org/10.2139/ssrn.2336016

Pitas, N., \& Ehmer, C. (2020). Social capital in the response to COVID-19. American Journal of Health Promotion, 34(8), 942-944. https://doi.org/10.1177/0890117120924531

Rupasingha, A., Goetz, S. J., \& Freshwater, D. (2006). The production of social capital in US counties. Journal of Socio-Economics, 35(1), 83-101. https://doi.org/10.1016/j.socec.2005.11.001

Rustiadi, E., \& Nasution, A. (2017). Can social capital investment reduce poverty in rural Indonesia? International Journal of Economics and Financial Issue, 7(2), 109-117. Retrieved from https://www.econjournals.com/index.php/ijefi/arti cle/view/3904

Sørensen, J. F. L. (2012). Testing the hypothesis of higher social capital in rural areas:The case of Denmark. Regional Studies, 46(7), 873-891. https://doi.org/10.1080/00343404.2012.669471

Sørensen, J. F. L. (2014). Rural-urban differences in bonding and bridging social capital. Regional
Studies, $1-21$. https://doi.org/10.1080/00343404.2014.918945

Todaro, M. ., \& Smith, S. C. (2014). Economic Development (Twelfth Ed). New Jersey: Pearson.

Uslaner, E. M. (2002). The Moral Foundations of Trust. https://doi.org/10.2139/ssrn.824504

van Ingen, E., \& van Eijck, K. (2009). Leisure and social capital: An analysis of types of company and activities. Leisure Sciences, 31(2), 192-206. https://doi.org/10.1080/01490400802686078

Van Oorschot, W., \& Finsveen, E. (2010). Does the welfare state reduce inequalities in people's social capital? International Journal of Sociology and Social Policy, 30(3-4), 182-193. https://doi.org/10.1108/01443331011033364

Veenhoven, R. (1989). Conditions of Happiness. Springer Science \& Business Media. 462p. https://books.google.co.id/books?id=cRIACQAAQ BAJ

Wang, R., Xue, D., Liu, Y., Chen, H., \& Qiu, Y. (2018). The relationship between urbanization and depression in China: The mediating role of neighborhood social capital. International Journal for Equity in Health, 17(1), 1-10. https://doi.org/10.1186/s12939-018-0825-x

Welan, V. P. R., Kawung, G. M. ., \& Tumangkeng, S. Y. (2019). Peran dana desa dalam memberdayakan ekonomi masyarakat Desa Ranowangko Kecamatan Tombariri. Jurnal Berkala Ilmiah Efisiensi, 19(04), 95-106. Retrieved from https://ejournal.unsrat.ac.id/index.php/jbie/article /view/26567

Widiyanti, E., Pudjihardjo, P., \& Saputra, P. M. A. (2018). Tackling poverty through women empowerment: the role of social capital in Indonesian women's cooperative. Jurnal Ekonomi dan Studi Pembangunan, 10(1), 44-55. https://doi.org/10.17977/um002v10i12018p044

Wooldridge, J. M. (2013). Introductory Econometrics: A Modern Approach, Fifth Edition. https://books.google.co.id/books?id=COKHwUKxy SOC

Zeho, F. H., Prabowo, A., Estiningtyas, R. A., Mahadiansar, M., \& Sentanu, I. G. E. P. S. (2020). Stakeholder collaboration to support accountability in village fund management and rural development. Journal of Socioeconomics and Development, 3(2), 89. https://doi.org/10.31328/jsed.v3i2.1395 
Appendix. Loading Factor, Variance, and Weight by Dimension and Indicator of Social Capital

\begin{tabular}{|c|c|c|c|c|c|c|c|}
\hline Dimension & Subdimension & Indicator & $\begin{array}{l}\text { Loading } \\
\text { Factor }\end{array}$ & $\begin{array}{c}\% \text { of } \\
\text { variance }\end{array}$ & $\begin{array}{l}\text { Name of } \\
\text { Factors }\end{array}$ & Weight & \begin{tabular}{|l|} 
Normalized \\
Weights for \\
Dimension
\end{tabular} \\
\hline$(1)$ & $(2)$ & (3) & (4) & $(5)$ & $(6)$ & $(6)$ & $(7)$ \\
\hline \multirow[t]{11}{*}{$\begin{array}{l}\text { Trust and } \\
\text { Tolerance }\end{array}$} & \multirow[t]{5}{*}{ Trust } & $\begin{array}{l}\text { Trust to commit the children to } \\
\text { neighbors }\end{array}$ & 0.8639 & \multirow[t]{2}{*}{6.75} & \multirow[t]{2}{*}{$\begin{array}{l}\text { Trust to } \\
\text { neighbors }\end{array}$} & 3.3992 & 0.1044 \\
\hline & & $\begin{array}{l}\text { Trust to commit the house to } \\
\text { neighbors }\end{array}$ & 0.8516 & & & 3.3508 & 0.1029 \\
\hline & & Trust in village's figures & 0.8346 & \multirow[t]{3}{*}{7.40} & \multirow{3}{*}{$\begin{array}{l}\text { Trust in } \\
\text { figures }\end{array}$} & 2.8182 & 0.0866 \\
\hline & & Trust in religious figures & 0.5457 & & & 1.8427 & 0.0566 \\
\hline & & Trust in village's apparatus & 0.8112 & & & 2.7392 & 0.0841 \\
\hline & \multirow[t]{3}{*}{$\begin{array}{l}\text { Religious } \\
\text { Tolerance }\end{array}$} & $\begin{array}{l}\text { Response to development of other } \\
\text { religion worship place }\end{array}$ & 0.8091 & \multirow[t]{3}{*}{9.27} & \multirow[t]{3}{*}{$\begin{array}{l}\text { Religious } \\
\text { Tolerance }\end{array}$} & 3.0849 & 0.0947 \\
\hline & & $\begin{array}{l}\text { Response to activities of other } \\
\text { religions }\end{array}$ & 0.8594 & & & 3.2767 & 0.1006 \\
\hline & & Different religion friendship & 0.7628 & & & 2.9084 & 0.0893 \\
\hline & \multirow{3}{*}{$\begin{array}{c}\text { Ethnic } \\
\text { Tolerance }\end{array}$} & Different ethnic marriage & 0.8272 & \multirow[t]{3}{*}{9.14} & \multirow{3}{*}{$\begin{array}{l}\text { Ethnic } \\
\text { Tolerance }\end{array}$} & 3.0946 & 0.0950 \\
\hline & & Different ethnic friendship & 0.8496 & & & 3.1783 & 0.0976 \\
\hline & & $\begin{array}{l}\text { Response to activities of other } \\
\text { ethnics }\end{array}$ & 0.7664 & & & 2.8671 & 0.0881 \\
\hline \multirow{6}{*}{$\begin{array}{l}\text { Collective } \\
\text { Action }\end{array}$} & \multirow[t]{2}{*}{ Reciprocity } & Easiness to get help & 0.7848 & \multirow[t]{2}{*}{5.70} & \multirow[t]{2}{*}{ Reciprocity } & 2.8087 & 0.1944 \\
\hline & & Ready to help others & 0.8079 & & & 2.8913 & 0.2001 \\
\hline & \multirow[t]{4}{*}{$\begin{array}{l}\text { Collective } \\
\text { Action }\end{array}$} & $\begin{array}{l}\text { Participation in joint activities to } \\
\text { public interest }\end{array}$ & 0.5707 & \multirow[t]{4}{*}{8.75} & \multirow[t]{4}{*}{$\begin{array}{l}\text { Collective } \\
\text { Action }\end{array}$} & 1.8603 & 0.1287 \\
\hline & & $\begin{array}{l}\text { Participation in religious social } \\
\text { activities }\end{array}$ & 0.7809 & & & 2.5455 & 0.1762 \\
\hline & & $\begin{array}{l}\text { Participation in joint activities to } \\
\text { assist people }\end{array}$ & 0.7895 & & & 2.5735 & 0.1781 \\
\hline & & $\begin{array}{l}\text { Participation in socieaty social } \\
\text { activities }\end{array}$ & 0.5432 & & & 1.7707 & 0.1225 \\
\hline \multirow{6}{*}{$\begin{array}{l}\text { Group and } \\
\text { Network }\end{array}$} & \multirow{4}{*}{$\begin{array}{l}\text { Participation } \\
\text { in Group }\end{array}$} & Frequency of community meeting & 0.8477 & \multirow[t]{4}{*}{13.82} & \multirow{4}{*}{\begin{tabular}{|l|} 
Participation \\
in Group
\end{tabular}} & 3.4892 & 0.1563 \\
\hline & & Society decision making & 0.8541 & & & 3.5155 & 0.1574 \\
\hline & & Participation in community meeting & 0.8897 & & & 3.6620 & 0.1640 \\
\hline & & $\begin{array}{l}\text { Participation in giving an opinion in } \\
\text { community meeting }\end{array}$ & 0.7661 & & & 3.1533 & 0.1412 \\
\hline & \multirow[t]{2}{*}{ Network } & Number of group participated & 0.9475 & \multirow[t]{2}{*}{8.51} & \multirow[t]{2}{*}{ Network } & 4.2642 & 0.1910 \\
\hline & & Position in group & 0.9434 & & & 4.2458 & 0.1901 \\
\hline
\end{tabular}

